\title{
STRUKTUR TULANG BELAKANG FETUS MENCIT (Mus musculus L.) SETELAH PEMBERIAN EKSTRAK ETANOL RIMPANG TEKI (Cyperus rotundus $\mathrm{L}$.)
}

\section{SPINAL STRUCTURES OF MICE FETUS (Mus musculus L.) AFTER TREATED BY RHIZOME ETHANOL EXTRACT (Cyperus rotundus $L$.)}

\author{
Etika Julitasari ${ }^{1 \star}$, Nuning Nurcahyani ${ }^{1}$, Hendri Busman ${ }^{1}$ \\ ${ }^{1}$ Jurusan Biologi FMIPA Universitas Lampung \\ JI. Prof. Dr. Sumantri Brojonegoro No.1, Bandar Lampung, 35145 \\ *e-mail: etika.julita@gmail.com
}

\begin{abstract}
ABSTRAK
Cyperus rotundus adalah rumput-rumputan yang tumbuh di berbagai habitat, digunakan dalam pengobatan tradisional karena dapat menormalkan siklus menstruasi, menghambat fertilisasi dan implantasi sehingga proses kehamilan sulit terjadi dan jika terjadi akan menyebabkan keliainan fetus. Rimpang teki mengandung alkaloid, flavonoid, tanin, glikosida, seskuiterpen dan saponin. Penelitian ini bertujuan untuk mengetahui pengaruh ekstrak etanol rimpang teki pada berat dan panjang fetus, serta struktur tulang belakang fetus. Percobaan dilakukan selama November 2015-Januari 2016 di Laboratorium Zoologi untuk pemeliharaan dan perlakuan hewan uji mencit (Mus musculus L.) dan di Laboratorium Kimia Organik untuk pembuatan ekstrak etanol rimpang teki. Penelitian menggunakan rancangan acak lengkap dengan 4 perlakuan dan 5 ulangan. Perlakuan pemberian dosis ekstraks etanol rimpang teki teridiri dari: kontrol diberi 0,4 $\mathrm{ml}$ aquabides ( A), 45 $\mathrm{mg}$ dalam 0,4 ml aquabides (B), $90 \mathrm{mg}$ dalam 0,4 ml aquabides (C), dan $135 \mathrm{mg}$ dalam 0,4 $\mathrm{ml}$ aquabides (D). Ekstrak etanol rimpang teki diberikan pada mencit hamil pada hari ke 6-17 kehamilan secara oral menggunakan sonde lambung. Berat dan panjang fetus dianalisis ragam dan dilanjutkan dengan uji BNT pada taraf $\alpha=5 \%$. Struktur tulang belakang fetus dianalisis secara deskriptif. Hasil penelitian menunjukkan bahwa rata-rata berat fetus yang diberi perlakuan menurun dibandingkan dengan kontrol, yaitu: 1,746 gram (A), 1,599 gram (B), 1,386 gram (C), dan 1,524 gram (D). Panjang rata-rata fetus yang diberi perlakuan meningkat dibandingkan dengan kontrol, yaitu : 2,84 cm (A), 2,95 cm (B), 3,22 cm (C), dan 3,13 cm (D). Diduga ekstrak rimpang teki mengandung zat aktif yang bersifat sitotoksik bagi fetus mencit. Ekstrak rimpang teki tidak menyebabkan kelainan pada struktur tulang belakang fetus. Hal ini diduga karena ekstrak rimpang teki juga mengandung kalsium sehingga dapat mempertahankan pertumbuhan dan perkembangan tulang.
\end{abstract}

Kata kunci: Cyperus rotundus, rimpang, Mus musculus, fetus, struktur tulang belakang

\begin{abstract}
Cyperus rotundus is a nut grass that grows in a variety of habitats. The $C$. rotundus rhizome is used in traditional medicine because it can normalize the menstrual cycle, inhibiting fertilization, and implantation so the process of pregnancy is difficult to occur and if a pregnancy occurs will cause fetal abnormalities. The nut grass rhizomes contain alkaloids, flavonoids, tannins, glycosides, sesquiterpenes and saponins. This research was conducted to observe the effect of $C$. rotundus nut grass rhizome ethanol extract on weight, length, and spinal structures of fetus. The experiments conducted during November 2015-January 2016 at the Laboratory of Zoology for maintenance and treating the test animals, mice (Mus musculus L.) and in Organic Chemistry Laboratory to prepare the extract ethanol of $C$. rotundus rhizome. This experiment used a completely randomized design with 4 treatments and 5 replications. The treatment dose of ethanol extract of $C$. rotundus rhizomes $\mathrm{C}$ consists of: control (A) $0.4 \mathrm{ml}$ aquabidest, $45 \mathrm{mg}$ extract in $0.4 \mathrm{ml}$ aquabidest (B), $90 \mathrm{mg}$ extract in $0.4 \mathrm{ml}$ aquabidest $(\mathrm{C})$, and $135 \mathrm{mg}$ extract in $0,4 \mathrm{ml}$ aquabidest (D). Nut grass rhizome ethanol extract was given to mice pregnant on 6-17 days of pregnancy orally using a stomach sonde The weight and length of fetuses analyzed using ANOVA and followed by LSD test at level $\alpha=5 \%$. Fetal spinal structures were analyzed descriptively. The results showed that the average weight of fetuses treated decreased compared with controls, namely: 1,746 grams (A), 1.599 grams (B), 1.386 grams (C), and 1.524 gram (D). The average length of fetuses treated increased compared with controls, ie: $2.84 \mathrm{~cm}(\mathrm{~A}), 2.95 \mathrm{~cm}(\mathrm{~B}), 3.22 \mathrm{~cm}(\mathrm{C})$, and 3.13 $\mathrm{cm}(\mathrm{D})$. This is presumably $C$. rotundus rhizome extract contained active substances that are cytotoxic to the mice fetus. C. rotundus rhizome ekstract does not cause abnormalities in spinal structures of fetus. This is presumably because $C$. rotundus rhizome extract contain calcium so that it can sustain the growth and development of bones.
\end{abstract}

Keyword: Cyperus rotundus, rhizome, Mus musculus, fetus, spinal structures 


\section{PENDAHULUAN}

Rumput teki (Cyperus rotundus L.) merupakan tumbuhan liar yang hidup di berbagai tempat terbuka sehingga termasuk sebagai gulma (Dalimartha, 2009). Masyarakat di berbagai daerah di Indonesia telah memanfaatkan rumput teki sebagai obat tradisional. Bagian rimpang digunakan untuk pengobatan karena memiliki khasiat sebagai antibakteri, obat peluruh haid dan kontrasepsi, menghambat penetrasi sperma, menghambat fertilisasi dan implantasi, sehingga proses kehamilan sulit terjadi dan apabila terjadi maka kemungkinan fetus akan mengalami kecacatan (Winarno dan Sundari, 1997).

Komponen aktif dalam rimpang teki adalah seskuiterpen dan berbagai bahan kimia yaitu alkaloid, flavonoid, tanin, pati, glikosida, dan saponin (Subhuti, 2005). Dengan adanya berbagai zat kimia tersebut maka dilakukan penelitian mengenai uji teratogenik dari ekstrak rimpang teki untuk mengetahui ada atau tidaknya kelainan pada fetus hewan uji berupa mencit (Mus musculus L.). Pada penelitian ini dilakukan pengamatan terhadap penurunan berat badan dan panjang fetus, serta kelainan pada struktur tulang belakang fetus mencit, dimana proses pembentukan dan perkembangan tulang (osifikasi) pada fetus mencit terjadi pada hari kehamilan ke-11 sampai ke-17 sehingga pada masa itu sangat rentan terhadap senyawa teratogen (Rugh, 1968).

\section{BAHAN DAN METODE Alat dan Bahan}

Alat- yang digunakan dalam penelitian ini adalah kandang mencit beserta penutup yang terbuat dari kawat sebanyak 20 unit, wadah pakan mencit, botol minum mencit, sonde lambung yang dihubungkan dengan alat suntik, mikropipet, tabung reaksi, rak tabung reaksi, erlenmeyer, gelas ukur, seperangkat alat bedah, kertas label, kamera tipe SM-J500G, botol film, jangka sorong, dan timbangan digital.

Bahan yang digunakan adalah 20 ekor mencit betina dan 20 ekor mencit jantan berumur 3-4 bulan dengan berat sekitar 40 gram, sekam padi, pelet, air minum mencit, ekstrak rimpang teki, aquabides, kloroform, kapas, alkohol 90\%, larutan $\mathrm{KOH} 1 \%$, larutan Alizarin Red, dan alkohol $70 \%$.

\section{Cara Kerja}

\section{Persiapan kandang dan hewan uji}

Kandang mencit beserta penutupnya sebanyak 20 unit dibersihkan dengan alkohol dan diberi alas berupa sekam padi. Mencit kemudian diaklimatisasi selama 1 minggu dengan diberi pakan berupa pelet dan air minum setiap harinya.

\section{Persiapan dan Pembuatan Ekstrak}

\section{Rimpang Teki}

Pembuatan ekstrak rimpang teki dengan metode maserasi. Rimpang teki dibersihkan, dicuci, dan dijemur hingga kering kemudian digiling hingga menjadi serbuk. Dilakukan maserasi dengan cara merendam 500 gram serbuk rimpang teki 
dalam 2 liter larutan etanol selama 24 jam. Kemudian disaring menggunakan kertas saring. Cairan hasil saringan tersebut lalu dipekatkan menggunakan alat rotary evaporator selama 4 jam dengan suhu $50^{\circ} \mathrm{C}$ dan tekanan $120 \mathrm{~atm}$.

\section{Pemberian Perlakuan}

Satu ekor mencit betina disatukan secara alami dengan satu ekor mencit jantan ke dalam satu kandang dan diberi pakan berupa pelet dan air minum. Pada pagi hari dilakukan pengamatan di daerah vagina pada mencit betina. Apabila ditemukan sumbat vagina, maka mencit dinyatakan telah melakukan kopulasi dan dihitung sebagai kehamilan hari ke-0 (Silvia, 2011).

Penelitian ini menggunakan Rancangan Acak Lengkap dengan 4 perlakuan dan 5 kali pengulangan. Pemberian ekstrak rimpang teki dilakukan dengan cara dicekok (secara oral) menggunakan alat sonde lambung mulai dari kehamilan hari ke 6 sampai ke 17 dengan dosis:

1. Kontrol, diperlakukan dengan diberi 0,4 $\mathrm{ml}$ aquabides $(\mathrm{A})$

2. Dosis $45 \mathrm{mg}$ dalam $0,4 \mathrm{ml}$ aquabides $(\mathrm{B})$

3. Dosis $90 \mathrm{mg}$ dalam $0,4 \mathrm{ml}$ aquabides (C)

4. Dosis $135 \mathrm{mg}$ dalam 0,4 $\mathrm{ml}$ aquabides (B)

\section{Pengamatan}

Pada kehamilan hari ke 18 mencit dibedah dan fetus dikeluarkan dari uterus, kemudian dibersihkan dengan air mengalir dan dilakukan penimbangan berat badan dan pengukuran panjang fetus. Selanjutnya dikeluarkan organ dalam fetus dan dilakukan preparasi tulang belakang fetus dengan pewarna Alizarin Red. Pembuatan larutan Alizarin Red dengan cara menambahkan 6 mg bubuk Alizarin Red ke dalam 1 liter larutan $\mathrm{KOH} 1 \%$ (Manson et al., 1982). Pengamatan struktur tulang belakang fetus dilakukan secara deskriptif untuk melihat ada atau tidaknya kelainan dibandingkan dengan fetus normal (kontrol).

\section{Analisis data}

Data hasil penelitian berupa anatomi tulang belakang fetus dianalisis secara deskriptif. Panjang dan berat fetus dianalisis menggunakan Analisis Ragam (ANARA). Apabila terdapat perbedaan yang nyata, maka akan dilakukan uji lanjut dengan uji beda nyata terkecil (BNT) pada taraf $5 \%$.

\section{HASIL DAN PEMBAHASAN}

\section{Berat Badan dan Panjang Fetus}

Pada kehamilan hari ke 18, induk mencit dibedah dan fetus dikeluarkan dari uterus. Data berat badan fetus mencit disajikan pada Gambar 1.

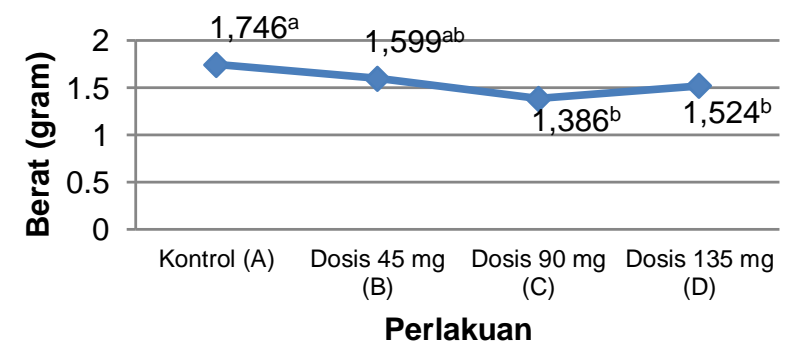

Gambar 1. Penurunan berat badan fetus setelah pemberian ekstrak rimpang teki. Angka yang diikuti huruf superskrip berbeda menunjukkan beda nyata berdasarkan uji BNT 5\% 
Berdasarkan Gambar 1, rata-rata berat badan fetus mencit yang diberi perlakuan mengalami penurunan berat badan apabila dibandingkan dengan fetus yang tidak diberi perlakuan (kontrol). Setelah dilakukan analisis varian dengan taraf signifikasi $5 \%$, menunjukkan hasil yang signifikan dan uji lanjut menggunakan BNT dengan taraf 5\% menunjukkan adanya perbedaan nyata antara kontrol dengan perlakuan dosis $90 \mathrm{mg}$ (C) dan perlakuan dosis $135 \mathrm{mg}$ (D), namun tidak ada perbedaan nyata antara kontrol dengan perlakuan dosis $45 \mathrm{mg}$ (B) dan antar perlakuan B, C, dan D. Data panjang fetus mencit disajikan pada Gambar 2.

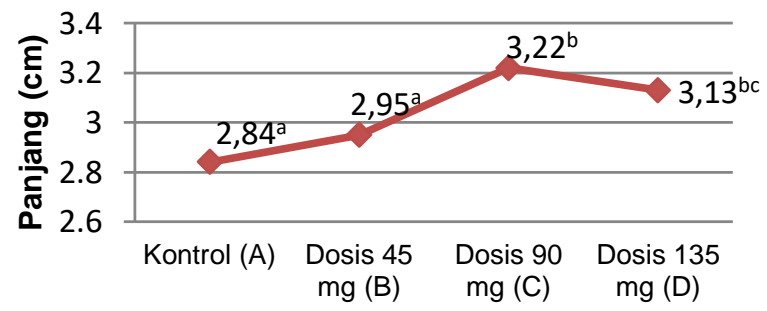

Perlakuan

Gambar 2. Pertambahan panjang badan fetus setelah pemberian ekstrak rimpang teki. Angka yang diikuti huruf superskrip berbeda menunjukkan beda nyata berdasarkan uji BNT 5\%

Berdasarkan Gambar 2, rata-rata panjang fetus mencit yang diberi perlakuan mengalami penambahan panjang badan apabila dibandingkan dengan fetus yang tidak diberi perlakuan (kontrol). Setelah dilakukan analisis varian dengan taraf signifikasi $5 \%$ dan uji lanjut menggunakan BNT dengan taraf 5\% menunjukkan adanya perbedaan nyata antara kontrol dengan perlakuan $\mathrm{C}$, kontrol dengan perlakuan $\mathrm{D}$, perlakuan $B$ dengan perlakuan $D$, namun tidak ada perbedaan nyata antara kontrol dengan perlakuan $B$, perlakuan $B$ dengan $D$, serta perlakuan $\mathrm{C}$ dengan $\mathrm{D}$.

\section{Tulang Belakang Fetus}

Fetus mencit yang sudah dikeluarkan dari uterus dan dibersihkan organ dalamnya kemudian dilakukan preparasi tulang belakang fetus menggunakan larutan Alizarin Red.

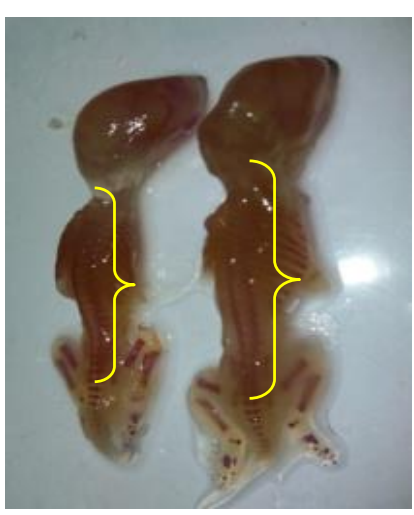

(a)

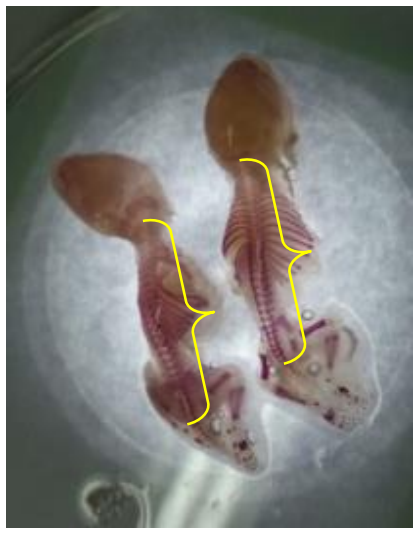

(c)

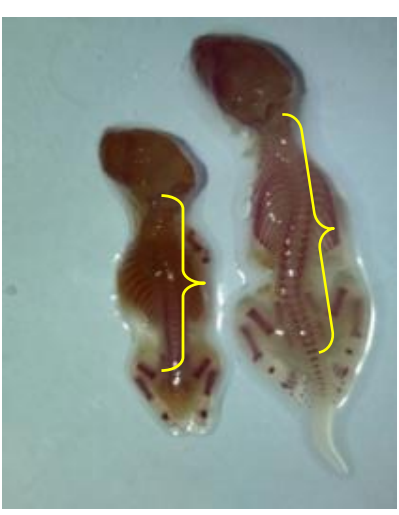

(b)

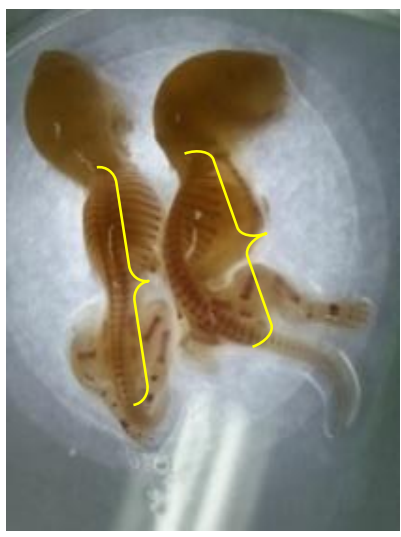

(d)
Gambar 3. Fetus dari perlakuan ekstrak etanol (a) Kontrol, (b) dosis $45 \mathrm{mg}$, (c) Dosis $90 \mathrm{mg}$, (d) Dosis $135 \mathrm{mg}$.

Berdasarkan Gambar 3, pengamatan terhadap tulang belakang fetus mencit dilakukan dengan cara mengamati struktur 
tulang belakang fetus meliputi servikalis, torakalis, dan lumbalis. Setelah dibandingkan antara tulang belakang fetus normal dan yang diberi perlakuan, tidak ditemukan adanya kelainan pada tulang belakang pada semua tingkatan dosis.

\section{Pembahasan}

\section{Berat Badan dan Panjang Fetus}

Pada penelitian ini dilakukan pengamatan terhadap berat badan fetus. Berat badan merupakan parameter penting untuk mengetahui efek teratogenik suatu senyawa terhadap fetus hewan uji yang ditandai dengan penurunan berat badan fetus (Wilson dan Warkany, 1965 dan Setyawati, 2009). Pada penelitian ini, berat badan fetus yang tidak diberi perlakuan (kontrol) lebih rendah dibandingkan fetus yang diberi perlakuan ekstrak rimpang teki

Penurunan berat badan fetus adalah efek dari pemberian ekstrak rimpang teki pada fase organogenesis sehingga menyebabkan kelainan berupa berat badan yang tidak normal. Berat badan yang tidak normal terjadi karena senyawa teratogen pada ekstrak rimpang teki mempengaruhi proliferasi sel, sehingga terjadi hambatan pada sintesis asam nukleat, protein, atau polisakarida (Wilson, 1973 dan Siburian dan Marlinza, 2009).

Pada saat fetus, sel-sel tubuh mampu membelah dengan cepat sehingga sangat rentan terhadap senyawa yang bersifat toksik yang diberikan kepada induk mencit saat kehamilan. Hal itu dapat terjadi karena ekstrak yang diberikan kepada induk mencit akan berpindah ke fetus melalui plasenta, yaitu melalui jalan yang sama yang dilalui oleh zat gizi yang diperlukan untuk pertumbuhan dan perkembangan fetus (Suryawati, 1990 dan Muna dll., 2011).

Ekstrak rimpang teki mengandung komponen aktif yaitu $\alpha$-cyperone, $\beta$-selinene, cyperene, cyperotundone, patchoulenone, sugeonol, kobusone, dan isokobusone serta berbagai bahan kimia yaitu alkaloid, flavonoid, tanin, pati, glikosida, dan saponin (Subhuti, 2005). Berbagai senyawa yang terkandung dalam ekstrak rimpang teki membuat ekstrak rimpang teki memiliki efek sitotoksik (Lawal dan Adebola, 2009). Dengan adanya efek sitotoksik dari ekstrak rimpang teki ini dimungkinkan dapat menyebabkan kematian beberapa sel sehingga menyebabkan berat badan fetus yang diberi perlakuan lebih rendah dibandingkan dengan kontrol.

Pertambahan panjang fetus dipengaruhi oleh hormon pertumbuhan yang akan mempengaruhi metabolisme protein, elektrolit, karbohidrat, dan lemak. Sekresi hormon pertumbuhan dikontrol oleh hipotalamus dengan cara mensekresi Growth Hormone-Releasing Hormone (GHRH) dan Growth Hormone-Inhibiting Hormone (GHIH) ke dalam darah yang akan mempengaruhi sel-sel tubuh dalam memproduksi hormon 
pertumbuhan. Pertambahan panjang badan fetus yang diberi perlakuan tersebut diduga karena kerja hipotalamus dalam mensekresi GHRH dan GHIH terganggu oleh adanya alkaloid, flavonoid, dan saponin dalam ekstrak rimpang teki yang merupakan xenobiont (zat asing dalam tubuh) (Widyastuti dll., 2006).

\section{Tulang Belakang Fetus}

Pengamatan terhadap tulang belakang fetus dilakukan secara visual dengan membandingkan tulang belakang fetus kontrol dengan fetus yang diberi perlakuan. Pada fetus normal (kontrol) terdapat 7 tulang servik, 13 tulang thorak, 6 tulang lumbalis, 6 tulang sakral, dan 2 atau 3 tulang kaudal (Sukandar dll., 2008). Setelah dibandingkan dengan fetus normal, pada fetus yang diberi perlakuan tidak ditemukan adanya kelainan pada tulang belakang fetus pada tingkatan dosis.

Terdapat 3 cara untuk mengetahui pertumbuhan dan perkembangan skeleton, yaitu jumlah komponen skeleton dan tingkat osifikasinya (sempurna atau tidaknya proses osifikasi), dan ada atau tidaknya kelainan dalam pembentukan skeleton. Berdasarkan hasil pengamatan pada penelitian ini menunjukan bahwa tidak terdapat kelainan pada struktur tulang belakang fetus mencit setelah diberi perlakuan ekstrak rimpang teki. Hal ini diduga karena di dalam ekstrak rimpang teki mengandung kalsium sebanyak $(16,40 \pm 0,32) \mathrm{mg} / 100 \mathrm{~g}$. Menurut Dewoto
(2007), nutrisi yang paling penting untuk pertumbuhan dan perkembangan tulang adalah kalsium. Kalsium memegang dua peranan fisiologis penting di dalam tubuh. Di dalam tulang, garam-garam kalsium berperan pada proses kalsifikasi, sehingga tulang menjadi keras. Pengerasan tulang berfungsi untuk menopang berat badan. Sedangkan di dalam cairan ekstraseluler dan sitosol, kalsium berperan pada berbagai proses biokimia tubuh dalam bentuk ion-ion kalsium (Setiyohadi, 2009).

Tidak terjadinya kelainan struktur tulang belakang pada fetus setelah diberi perlakuan ekstrak rimpang teki juga disebabkan oleh fetus yang sedang tumbuh mengambil prioritas dari banyaknya jenis nutrisi dalam cairan induk sehingga tulang fetus dapat terus tumbuh dan berkembang. Hal ini berhubungan dengan fungsi plasenta sebagai tempat penyimpanan nutrisi bagi fetus. Plasenta menyimpan sejumlah besar nutrisi seperti kalsium, besi, protein, dan glukosa yang digunakan untuk pertumbuhan fetus. Selain plasenta, sebagian kalsium juga disimpan dalam tubuh induk seperti pada gigi dan tulang. Apabila kebutuhan kalsium fetus berkurang maka simpanan kalsium pada tulang dan gigi inilah yang akan dimobilisasi untuk osifikasi tulang pada fetus (Guyton, 1990). 


\section{KESIMPULAN DAN SARAN}

\section{Kesimpulan}

Berdasarkan hasil penelitian dapat diambil kesimpulan bahwa pemberian ekstrak rimpang teki pada mencit hamil memberikan pengaruh menurunkan berat badan fetus dan menambah panjang fetus mencit. Namun, tidak menyebabkan kelainan pada struktur tulang belakang fetus mencit.

\section{Saran}

Perlu dilakukan penelitian lebih lanjut mengenai zat atau kandungan spesifik dalam ekstrak rimpang teki yang dapat menyebabkan efek teratogen terhadap fetus mencit.

\section{DAFTAR PUSTAKA}

Dalimartha, S. 2009. Atlas Tumbuhan Obat Indonesia Jilid 6. Pustaka Bunda. Jakarta. p 157

Dewoto, H.R. 2007. Farmakologi dan Terapi: Vitamin dan Mineral Edisi 5. Balai Penerbit FK UI. Jakarta.

Guyton, A.C. 1990. Fisiologi Kedokteran. Terjemahan Dharrna, A., dan P., Lukmanto. EGC. Jakarta.

Lawal, O.A. dan Adebola, O.O. 2009. Chemical Composition of The Essential Oils of Cyperus rotundus L. from South Africa. Journal Molecules. 14 (150). pp 29092917.

Manson, J.M., Zenick, H., and Costlow, R.D. 1982. Teratology Test Method for Laboratory Animals. Ravent Press. New York.
Muna, L., Astirin, O.P., dan Sugiyarto. 2011. Uji

Teratogenik Ekstrak Pandanus conoideus varietas buah kuning Terhadap Perkembangan Embrio Tikus Putih (Rattus norvegicus). Nusantara Bioscience. 2. pp 126-134.

Rugh, R. 1968. The Mouse : Its Reproduction and Development. New York. Burger Publishing Company. p 20

Setiyohadi, B. 2009. Peran Kalsium dan Vitamin $D$ Pada Metabolisme Tulang. Subbagian Reumatologi, Bagian IImu Penyakit Dalam FKUI/RSCM. Jakarta.

Setyawati, I. 2009. Penampilan Reproduksi Dan Perkembangan Skeleton Fetus Mencit Setelah Pemberian Ekstrak Buah Nanas Muda. Jurnal Veteriner. 12 (3). pp $192-$ 199.

Siburian, J. dan Marlinza, R. 2009. Efek Pemberian Ekstrak Akar Pasak Bumi (Eurycoma Longifolia Jack) Pada Tahap Prakopulasi Terhadap Fertilitas Mencit (Mus Musculus L.) Betina. Biospesies. 2 (2). pp 24-30.

Silvia, G.A. 2011. Pengaruh Pemberian Suspensi Sari Akar Manis Terhadap Perkembangan Janin Pada Mencit Bunting. (Skripsi). FMIPA Universitas Indonesia. Jakarta. p 14-15.

Subhuti, D. 2005. Cyperus Primary Oil Regulating Herb of Chinese Medicine. Institute For Traditional Medicine. Oregon Portland. p 2.

Sukandar, E.Y., Fidrianny, I., dan Garmana, A.N. 2008. Pengaruh Kombinasi Ekstrak Umbi Lapis Bawang Putih dan Ekstrak Rimpang Kunyit Tehadap Janin Mencit Swiss-Webster. JKM. 8(1). pp 36-44.

Suryawati, S. 1990. Pemakaian Obat Pada Kehamilan. Laboratorium Farmakologi Klinik Fakultas Kedokteran Universitas Gadjah Mada. Yogyakarta. 
Widyastuti, N., Widiyani, T., dan Listyawati, S.

2006. Efek Teratogenik Ekstrak Buah

Mahkota Dewa (Phaleria macrocarpa

(Scheff.) Boerl.) pada Tikus Putih (Rattus norvegicus L.) Galur Winstar.

Bioteknologi. 3 (2). pp 56-62.

Wilson, J.G. 1973. Environment and Birth

Defects. Academic Press. New York. pp.68.

Wilson, J.G. and Warkany, J. 1965. Teratology Principles and Techniques. University of Chicago Press. Chicago and London. p 16-18.

Winarno, W.M. dan Sundari, M. 1997. Informasi Tanaman Obat Untuk Kontrasepsi Tradisional. Pusat Penelitian Dan Pengembangan Farmasi. Badan Penelitian Dan Pengembangan Kesehatan Departemen Kesehatan RI. Jakarta. 